

\title{
Mi mirada en el espejo: el autorretrato como afirmación del autor. Una etnografía del campo fotográfico argentino ${ }^{1}$
}

\section{My look in the mirror: the self-portrait as an author's affirmation. An ethnography of the Argentinean photographic field}

\author{
Agustina Triquell*
}

\begin{abstract}
Resumen: Si hacemos un recorrido por la producción fotográfica de autor en la Argentina de los últimos treinta años, veremos diversas manifestaciones del género del autorretrato, utilizando un sinfin de recursos expresivos y estrategias enunciativas. El artículo se propone revisar, desde una perspectiva etnográfica, las relaciones entre campo fotográfico de autor y la elaboración de una imagen del yo, como modos de enunciación de una subjetividad con estrategias especificas y selectivas de aparición.
\end{abstract}

Palabras clave: Autorretrato. Campo fotográfico. Fotografía Argentina.

\begin{abstract}
If we look at the photographic production in Argentina author of the last thirty years, we will see various manifestations of the genre of self-portrait, using a wealth of expressive resources and declarative strategies. The paper intends to review, from an ethnographic perspective, the relationship between authors and the development of an image of self, such as the modes of enunciation of their subjectivities.
\end{abstract}

Keywords: Self-portrait. Photographic Field. Argentine Photography.

\footnotetext{
* Doctora en Ciencias Sociales y fotógrafa. Desde 2012 forma parte del Programa de Ciudadanía y Derechos Humanos del Centro de Investigaciones Sociales del Instituto de Desarrollo Económico y Social (CIS-IDES) en Buenos Aires.

1 Este artículo recoge algunos de los resultados del proyecto "Espejos distorsionados, cercanos y distantes: experiencias de configuración de subjetividades en imágenes fotográficas autorreferenciales", becaria doctoral, Consejo Nacional de Investigaciones Científicas y Técnicas (CONICET), Buenos Aires, Argentina (2012-2014).
} 


\section{Introducción}

Si hacemos un recorrido por la producción fotográfica de autor en la Argentina de los últimos treinta años, veremos diversas manifestaciones del género del autorretrato, utilizando un sinfín de recursos expresivos y estrategias enunciativas. Los discursos autorreferenciales en general y el autorretrato en particular entendido como la imagen resultante de la situación en la que el propio autor posa por delante de la cámara y opera sobre las decisiones técnico-estéticas de la toma- poseen un lugar central en la historia de la fotografía de autor. En algunos de los/as autores/ as argentinos/as contemporáneos/as, de variadas generaciones, la apelación a esta estrategia aparece desde sus primeros trabajos, en sus primeras exploraciones con la cámara y, en algunos/as de ellos/ as se mantiene o reaparece en distintos momentos a lo largo de su carrera.

Tenía la sospecha que para ingresar como realizador de imágenes fotográficas al campo artístico, qué mejor para los incipientes autores que "tomar prestado" un género propio de la historia de la pintura y que se aleja además de los usos amateurs o laborales -fotografía de prensa, comercial, publicitaria-propios del medio fotográfico. A esto se le suma que el ejercicio del autorretrato pictórico es un género propio de las narrativas visuales del Yo desde el Renacimiento: la contemplación reflexiva que da como resultado -mediante una resolución estética particular- la presentación de cierto aspecto -físico y psicológico- del perfil del artista. Entendido en estos mismos términos, el autorretrato fotográfico es una práctica fundacional de subjetividad, en tanto propone la configuración de un sujeto-artista, de un sujeto-fotógrafo/a.

Fue esta sospecha la que fue llevando a elegir los y las autores/as con los que comenzar este recorrido. El primer acercamiento fue a los/as fotógrafos/as consagrados/as con más de treinta años de trayectoria y con espacios de formación como talleres y clínicas en los que se han formado autores más jóvenes: 
Adriana Lestido, Juan Travnik, Alberto Goldenstein, Eduardo Gil y Ataúlfo Pérez-Aznar. Todas las voces que aquí aparecen, fueron obtenidas mediante entrevistas en los estudios u hogares de los/as autores/as, mientras compartíamos un recorrido por su obra a través de catálogos, publicaciones y fotografías exhibidas en la pared.

De ese primer grupo se desprendieron otras dos entrevistas: a Daniel Merle y a Julie Weisz, pertenecientes al mismo grupo generacional que los primeros pero con trayectorias y campos de consagración diferentes. La decisión de entrevistar a Merle tenía con ver con un interés por su muestra "Mala Memoria" y en el caso de Weisz por su trabajo "Autorretratos circulares".

A partir de ese primer grupo de entrevistados, fui incorporando a otros/as, por sus referencias y señalamientos en torno a sus obras. Al acercarme a las imágenes efectivamente comprobé que la incorporación del autorretrato en autores/as fotógrafos/as fue incrementándose con el correr de las décadas, y los recursos estéticos fueron ampliándose con la incorporación de otras tecnologías para la generación de imágenes fotográficas. Si bien todos/as dijeron haberse autorretratado alguna vez, estas imágenes no en todos los casos pertenecen al cuerpo de obra ni son exhibidas en el marco de su propio trabajo autoral. Y allí es dónde la cuestión se complica: si bien todos/as lo hacen, no todos ponen estas imágenes en circulación. En este punto reside la mayor diferencia: en las esferas de circulación elegidas para este tipo de imágenes. En algunos casos, aparecen como un ejercicio íntimo, en otros, es el cuerpo mismo de la obra definido y titulado en términos de "autorretratos", y es exhibido bajo esa nominación.

Esta diferencia en relación a la actitud sobre el autorretrato aparece en el diálogo con Daniel Merle, quien traza una línea que define dos conjuntos: los "establecidos" y los "emergentes", que se vinculan con lo autorreferencial de manera diferenciada. Los establecidos - delimitados como "los que tienen obra que cotiza en el mercado del arte y que tienen muestras y libros"- considera que hay pocos autorretratos en el cuerpo de su obra "más conocida" 
pero que sí han desarrollado exploraciones en el género en muestras colectivas, mientras que entre los emergentes, el trabajo es "más autorreferencial". Esto es, un campo semántico anclado en su vida íntima, que aborda sus vínculos inmediatos y desarrolla sus temáticas en la esfera privada.

Lo que Merle establece como distinción no es el tipo de prácticas de unos/as y otros/as, sino lo que efectivamente se comercializa en el mercado, lo que deciden incluir dentro -0 las lógicas del mercado deciden dejar fuera- del cuerpo de su obra. Si bien tanto unos/as como otros/as desarrollan imágenes en las que se exponen ante la cámara, las decisiones estéticas son diferentes. Merle define la práctica de los emergentes en términos de "más autorreferencial", mientras que para referirse a la práctica de los establecidos habla de "autorretratos", como una práctica anclada al canon, a las convenciones del género. Esta no es una diferencia menor; volveremos sobre este punto más adelante.

Lo que aparece aquí, por debajo del comentario de Daniel Merle, es que la constante pugna entre el campo del arte y el campo fotográfico - de entradas y salidas, de diálogos y negociaciones entre uno y otro- entre el mercado y la consagración, se manifiesta también en este uso específico de la imagen. Allí donde los modos en que la fotografía plantea y elabora sus estrategias de ingreso al campo del arte aparece una apelación a géneros y estéticas tradicionales ya consagrados en dicho campo.

La legitimación de la fotografía como práctica artística en Argentina contempló diferentes etapas y actores: quienes venían del campo de las artes visuales y quienes venían del oficio fotográfico llevaron adelante este proceso y marcaron así también espacios de consagración para unos y para otros. Mientras que los primeros incorporaron la fotografía en diálogo con otros lenguajes (el dibujo, la pintura, la instalación y la performance) los segundos se mantuvieron en un modo de trabajo propio, el del ensayo fotográfico, en el que diversas temáticas eran abordadas y narradas en series fotográficas, respetando en mayor o menor medida una serie de 
reglas narrativas que estos formatos poseen. Así, los primeros se acercaban a los espacios de consagración de los museos y salones nacionales, mientras que los segundos apelaron a nuevos espacios consagratorios, como los premios y salones exclusivamente de fotografía, los tradicionales premios de las distintas asociaciones de reporteros gráficos regionales y de la asociación nacional (ARGRA), así como los concursos fotográficos de ciertas empresas o publicaciones que proponen dos categorías (profesionales y aficionados) en algunos casos definiendo una temática previa.

Si bien la distinción entre artistas visuales y fotógrafos pareciera haber sido superada, en el año 2010 en el marco de la semana de encuentros del Festival de la Luz, una de las mesas de debate programada se titulaba “¿Fotógrafos o artistas visuales?” e invitaba a tres figuras del campo fotográfico de autor-Juan Travnik, Eduardo Gil y Fabiana Barreda- a sentar sus posiciones.

Al respecto Travnik comenta: "cuando me llama Silvia Mangialardi, la organizadora de los Encuentros Abiertos del Festival de la Luz, me pregunta: ¿vos te considerás fotógrafo o artista visual? Cuando yo le contesto que fotógrafo me dice iyo sabía que ibas a contestar eso! Te pusimos en una mesa en la semana de encuentros del festival, y ahí me cuenta quiénes eran los otros, entonces yo le digo, ¿y Eduardo dijo que era artista visual no?" Los posicionamientos en el campo ya son conocidos entre los integrantes de la generación de "consagrados" (utilizando la categoría del modo que lo propone Merle) así como las estrategias de consagración de unos/as y otros/as.

La posición de Travnik fue clara: él se considera fotógrafo, porque piensa su trabajo netamente en términos fotográficos, sin haber incursionado nunca en otros lenguajes artísticos. Si bien esta controversia, creada por los organizadores y planteada de esta manera para favorecer el debate, pareciera estar presente incluso entre las generaciones más jóvenes, aunque para los "emergentes" los límites en las esferas de circulación son más difusos.

Cuando en el año 2007, Nicola Constantino gana el mayor 
premio de fotografía del país (el Gran Premio de Honor del Salón Nacional) justamente con un autorretrato -titulado de esa maneracon una fotografía en la que ella posa (pero no opera la cámara), genera cierto recelo en la comunidad fotográfica. Aquellos que se definen como fotógrafos consideran importante cierto saber en torno a la técnica. "¿Acaso la categoría del Salón de Fotografía no era para fotógrafos? Una fotografía producida en estas condiciones ¿no debería competir en otra categoría? Es complicado, porque tampoco sería pintura, es una foto pero ella no es fotógrafa!" señala una de las entrevistadas.

Todo este tipo de valoraciones y categorizaciones implícitas dan cuenta de una necesidad del campo fotográfico de diferenciarse pero a su vez de ser parte del campo del arte argentino contemporáneo, en el que la fotografía tuvo, durante la década del noventa, un lugar de privilegio.

Una de las estrategias que los fotógrafos eligieron para alejarse de los usos comerciales de la imagen fotográfica y poder desarrollar un discurso propio con sus imágenes, fue el desarrollo de experimentaciones visuales en torno al autorretrato que constituyeron -y constituyen aún- un terreno de exploración significativo para tal fin. El acercamiento al autorretrato habilita entonces la posibilidad de alejarse del imaginario del fotógrafo como mero operador de la cámara, poniendo en escena una subjetividad que trasciende la destreza técnica y busca una cierta legitimidad entre una comunidad de virtuosos, en la que el ejercicio de colocarse por delante de la cámara manifiesta un rito de pasaje que implica dejar de entender a la cámara como un instrumento de trabajo para convertirse en un espejo de su mirada, sobre sí mismo y -posteriormente quizássobre el mundo. Quienes ejercen la fotografía de autor saben que su práctica debe presentarse ante los demás como desinteresada, que deben saber separar la lógica comercial del oficio de su potencial creador de otros discursos "artísticos".

Así, tanto el autorretrato como la fotografía autorreferencial se presentan como estrategias -más o menos desarrolladas, más 
o menos conscientes- de ingreso y consagración en el campo de la fotografía de autor. Los modos -señalados y diferenciados en la entrevista a Merle- en que tales estrategias son llevadas adelante varían en función del género de los/as autores/as y el grupo generacional al que pertenecen, así como también a las vinculaciones que establecen con el campo del arte en general y con el campo fotográfico en particular.

A lo largo de este artículo, atenderemos a una serie de modos de construcción de repertorios fotográficos autorreferenciales entre autores/as fotógrafos/as argentinos/as de las últimas cuatro décadas, tomando como referencia los circuitos elegidos para su circulación. Con este recorrido, pretendemos dar cuenta de la complejidad del campo y sus estrategias, mirando a través de una práctica específica, como lo es la construcción de repertorios fotográficos autorreferenciales.

\section{El autorretrato como (auto)afirmación del autor}

Comenzaré con un breve recorrido histórico que nos permitirá ubicar los fenómenos que son de nuestro interés. A comienzos de la década del setenta, los/as referentes del naciente campo fotográfico de autor instalaban -sin manifiestos más los que su propia prácticalos "requisitos" para ingresar en las lógicas del arte y la necesidad de alejarse de la dogmática del fotoclubismo. La década del ochenta constituyó el ingreso de la fotografía en el mercado del arte a nivel internacional, mientras que, a nivel local, los cimientos del campo se comenzaban a levantar: "podría decirse que los primeros años de conformación del campo se caracterizaron por un despertar amplio, ambicioso, ecléctico y amateur que movilizó a los actores detrás de temas clásicos del debate fotográfico, de la historia de la fotografía local y del mismo presente histórico" (PÉREZ FERNÁNDEZ, 2011, p.35).

En los años ochenta, durante los primeros años de actividad 
propia del campo fotográfico en el marco de la apertura democrática, los abordajes estéticos dominantes fueron el paradigma modernista y el registro documental. El primero, se inscribe dentro de la vanguardia y se proponía capturar el ritmo de la era moderna, el lugar de la máquina, la vida en las ciudades. Utilizaban composiciones simples, con una importante presencia de la geometría y al ritmo de la imagen, con un manejo consciente y cuidado de la luz. El exponente de referencia de la generación anterior es Horacio Coppola, que -habiendo estudiado en la escuela alemana de la Bauhaus- se convirtió en unos de los eslabones fundamentales para la llegada de dicha estética al país.

Por su parte, el paradigma documental se apoya en el registro indicial realista, el abordaje de una temática en profundidad y su estructuración bajo la forma de ensayos o series. Si bien prevalecen las temáticas de corte social y de denuncia, el registro de la vida privada se realiza, en grandes rasgos, bajo la misma resolución estética que se le aplica a los "grandes temas": fotografía directa, blanco y negro, retratos contextualizados con lo que rodea al personaje.

Tanto quienes se inscribían en uno como el otro, reconocen haberse autorretratado, algunos llevaron esta inquietud más allá e incluyeron el autorretrato en su propia obra. Los primeros, con imágenes que exploraban cuestiones formales -incorporación de reflejos, juegos de geometría y fotomontajes en ampliadora, por ejemplo- y los segundos con registros de su propia imagen en algún espejo "para terminar el rollo" o alguna "sombra curiosa". En muchas de estas imágenes, aparece la cámara fotográfica en el reflejo o en la sombra.

La generación encargada de dar consistencia al campo fotográfico de autor en Argentina comenzó a principios de los años ochenta a autorretratarse, tímidamente e imitando a ciertos autores norteamericanos y europeos que ya tenían repercusión internacional. En este momento, una de las manifestaciones más significativas en términos de esferas de circulación de estas imágenes- fueron 
las muestras colectivas organizadas por la galería Omega, "Los Fotógrafos - Autorretratos", cuya primera edición se realizó en 1983, y se reeditó, convocando a otros autores en 1990, 1996 y 2000. En cada muestra, cada autor participaba con un autorretrato de su autoría. En 1985, el Grupo de Fotógrafos (GUF), integrado por Elías Mekler, Filiberto Mugnani, Cristina Sarasa, Ricardo Tegni y Gabriel Valansi realizaron una serie de retratos de sí mismos en tanto grupo, que expusieron bajo el título $5 \times 5$ en la Fotogalería del Teatro Municipal General San Martín (PÉREZ FERNÁNDEZ, 2011).

Ataúlfo Pérez Aznar, curador de la serie de muestras de "Los fotógrafos" de la galería Omega, no puede separar su práctica como fotógrafo del autorretrato: es una búsqueda constante, presente "en todos mis negativos, o en casi todos". En el año 2012 editó una muestra retrospectiva recuperando esos autorretratos en la Fundación Lebensohn, en los que incluye por ejemplo fotos de él junto a su familia. Cuando comenzó a editar la muestra, notó, con cierta sorpresa, la cantidad que tenía y lo sostenida en el tiempo que había permanecido esta práctica.

Figura 1 - Ataúlfo Pérez Aznar

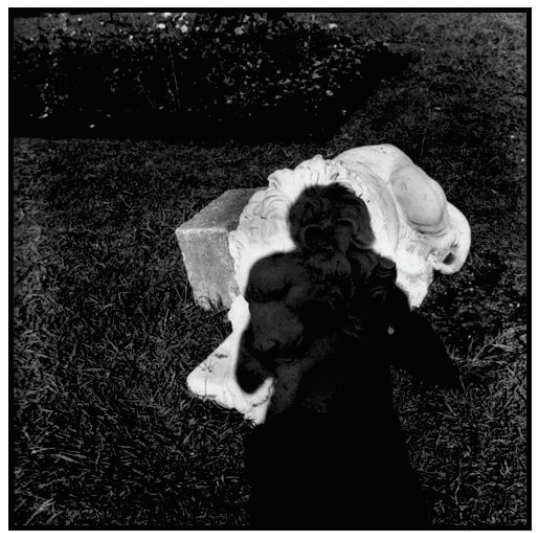

Fonte: Autorretratos 
En esta fotografía (figura 1), Ataúlfo Pérez Aznar proyecta su sombra sobre una escultura de un león, apunta la cámara y se registra sobreimpreso. La cámara que apunta -como escopeta de caza- establece una relación entre el animal y quién apunta, en este caso, Pérez Aznar. Es un león inmóvil y un arma que sólo apunta para registrar una mirada. Tampoco vemos la cámara que ha quedado fundida en la sombra misma de fotógrafo, pero podemos completar la figura -el contenido del contorno que la sombra señala- a partir de la pose allí definida. En la serie completa de los autorretratos de Ataúlfo esta operación se repite varias veces, proponiendo siempre una vinculación de sentido entre su sombra y la superficie sobre la que la proyecta.

Podemos señalar variadas estrategias para construir un discurso autorreferencial dentro del cuerpo de la obra de un/a autor/a. La definición de algunas de ellas tiene que ver con el momento del campo fotográfico de autor, y de sus relaciones con otros lenguajes como, principalmente, la pintura, la performance y las artes escénicas. Otras tienen que ver con la historia de vida del autor, con la elección de hacer referencia a fenómenos más amplios de la realidad político cultural del país o del mundo, y su inscripción en ella. En algunos/as autores/as, la construcción de sus imágenes se define en el señalamiento de una relación con un otro y a partir de ese vínculo, elaboran su discurso a partir de esa relación.

El trabajo de Lucila Quieto "Arqueología de la ausencia" (figura 2) parte de una inquietud personal, de una imagen faltante: no tener fotografías junto a su padre, Carlos Alberto Quieto, desaparecido antes del nacimiento de la autora. Para buscar esa imagen imposible exploró archivos familiares, realizó collages, construyó árboles genealógicos. Finalmente proyectó la imagen de su padre desde una diapositiva sobre la pared. Al principio, se retrató a sí misma mirando desde un margen exterior la imagen proyectada (LONGONI, 2009). Luego se interpuso en la imagen. "Lo que tengo que hacer, me dije, es meterme en la imagen, construir yo esa imagen que siempre había buscado, hacerme parte de ella". 
Una vez creado el mecanismo, Lucila invitó a otros hijos e hijas a generar estas imágenes. Así, "Arqueología de la ausencia" no son sólo sus propias imágenes sino que también las de otros trece hijos, trece historias más, en las que su propio retrato convive con los de otros hijos e hijas y sus padres. El mecanismo consistía en que hijos e hijas le acercaban a Lucila las fotografías de sus padres y ella los reproducía en una diapositiva. Luego, se juntaban a proyectar las imágenes y hacer las nuevas fotos, las que finalmente formarían parte de la serie.

Figura 2 - Lucila Quieto

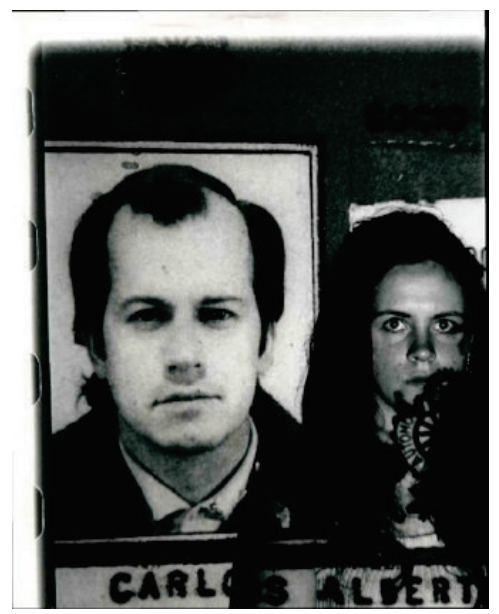

Fonte: Arqueología de la ausencia (1999-2001)

En el trabajo de Quieto, la historia personal se encuentra inscripta en la historia política y cultural del país. Comienza con una motivación personal que luego se proyecta hacia una comunidad afectada de una manera similar por el mismo acontecimiento. Pero hay algo más, que aparece en este encuentro, en este "tercer tiempo" imposible, que es la aparición de los rasgos comunes, los gestos, la fisionomía heredada, la filiación. En este tiempo, en esta contemporaneidad de elementos, Lucila tiene una edad cercana a la 
de su padre (al momento de haber sido fotografiado). Es aquí en donde el trabajo adquiere una nueva dimensión: no es sólo la inscripción histórica de la imagen, el hecho de ser hija de desaparecidos sino la imagen que busca una inscripción dentro de una genealogía: es, en este sentido, una fotografía familiar que ha sido manipulada para lograr esta particular convivencia de temporalidades.

Pasemos a otro trabajo, que se construye de una manera diferente. En el trabajo de Julie Weisz (figura 3), la autora no marca una distinción clara entre el retrato y el autorretrato: "en esos autorretratos que me hice en los noventa, que es la época más intensa, donde yo empiezo a tener, no sé yo supongo que estaría buscando mi identidad pero también desde esos años empiezo un trabajo de identidad femenina en una comunidad étnica en Formosa. Sería en el fondo una cuestión de inseguridad; yo siempre fui muy linda y sin embargo creo que no me tenía mucha conciencia, entonces me buscaba... ¿cómo era? ¿cómo era? y cómo me veían. Los retratos de las mujeres tobas son también autorretratos... con esas fotos yo buscaba la identidad femenina... qué era ser mujer... y entonces estaba [en la serie] esa foto de la mujer toba embarazada" (figura 3 , izquierda).

Las fotografías de esas otras mujeres son también para Weisz autorretratos, son su manera de poner en escena su identidad femenina: mediante la apelación de un cuerpo de otra (radicalmente otra), con la que sólo se comparte la condición sexual de ser mujer. "En 1990 comencé a investigar el tema del autorretrato. A medida que el tiempo pasaba y los cambios de mi vida se iban sucediendo, yo me ponía frente a la cámara y sentía que cuando me tomaba la foto dejaba la angustia impresa en la emulsión. En imágenes como la de la mujer embarazada y la mano en la terapia intensiva en que no soy yo, me siento reflejada y son una parte de mi historia, soy yo muriendo y soy yo pariéndome a mí misma. Por eso el nombre de "autorretratos circulares", como los ciclos de la vida". 
Figura 3 - Julie Wiesz

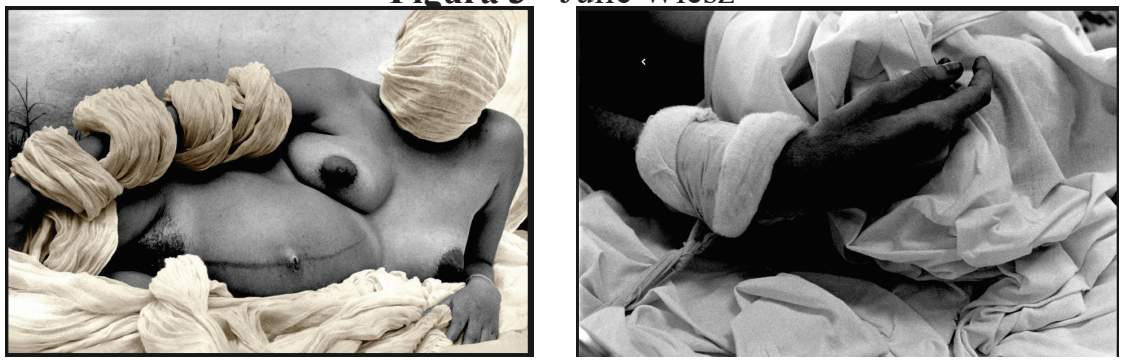

Fonte: Autorretratos circulares

Mientras que en el trabajo de Quieto se parte de lo particular que luego trasciende a otras historias similares, en el trabajo de Weisz, se recurre a otras mujeres para narrar una historia única, que se pretende universal, en términos de "ciclos de la vida". Mientras que la subjetividad que se propone en las fotografías de Quieto se funda en marcas sociohistóricas y aparecen las referencias a sujetos individuales (incluso con nombre y apellido), el trabajo de Weisz utiliza otros cuerpos, de otras mujeres, para diluirse en una condición de género, de una experiencia de vida relatada en una primera persona, aunque recurra al cuerpo de otras mujeres para construir el sentido de la serie. En la serie de Weisz conviven imágenes de distintas procedencias. Así como las dos imágenes de arriba (figura 3) son otras mujeres que representan el nacimiento y la muerte, en la serie aparecen otras representaciones sobre el sujeto, como por ejemplo imágenes de su infancia provenientes de su propio álbum familiar y la fotografía carnet.

En una de las piezas, conformada por un mosaico de fotografías carnet, múltiples mujeres (algunas incluso repetidas) posan ante la cámara. Son imágenes provenientes del estudio fotográfico comercial que la familia tuvo durante muchos años. Weisz se apropia de estas imágenes, las multiplica y pone en relación. Una vez más, la propia imagen se construye desde lo múltiple.

Hay otras maneras de entender la relación entre los registros 
familiares y el cuerpo de la propia obra fotográfica. Cuando Daniel Merle habla de su trabajo establece un juego entre sus registros domésticos y la fotografía "de la realidad": "lo que a mí me resultó muy interesante fue que yo podía vincular entre las fotos contemporáneas una movilización en la calle y contemporáneamente mis hijas jugando en su cuarto, vincular esas dos realidades y ampliar el espectro del público... porque en realidad una foto familiar está siempre bastante descontextualizada, no podés fijarte más que en la ropa a lo sumo, ahora si vos la contextualizás en otra foto de la realidad se potencia... y me gustó esa experiencia."

Son autorretratos que se proponen recuperar una esfera de lo doméstico, de la vida familiar, del paso del tiempo: son esferas diferentes, para Merlela fotografía familiarestá "descontextualizada" y se "potencia" con otra "foto de la realidad". Aquí aparece otra cuestión: la fotografía "de la realidad" a la que hace referencia es la fotografía de la realidad sociopolítica del país, ya que su trabajo era el de reportero gráfico y constantemente se encontraba fotografiando acontecimientos de la agenda pública. Cuando Merle señala que la decisión de "vincular esas dos realidades" para "ampliar el espectro del público" pone en evidencia que la significación que él le otorga a esa imagen no es la misma que la que le puede otorgar el espectador. Cuando piensa en términos de "ampliación del espectro del público", piensa en que es necesario la inclusión de imágenes de un dominio externo al del registro del álbum familiar, cuya significación y puesta en valor pareciera ser para Merle exclusiva de los miembros del colectivo familiar que allí se presenta.

Los trabajos que hemos visto hasta aquí se inscriben dentro del campo fotográfico, dialogan y transitan sus circuitos exhibidores. Veamos ahora qué sucede con las imágenes fotográficas que se inscriben en el campo del arte contemporáneo. 


\section{Lo autorreferencial como campo ampliado: Artistas visuales y fotógrafos.}

Con el correr del tiempo y con la llegada la década del noventa, el autorretrato propiamente dicho fue dejando de tener protagonismo frente a la proliferación de otro tipo de formatos autorreferenciales, en los que los elementos visuales elegidos eran variables, constituían citas a la historia personal, incorporaron materiales de archivos familiares y de esta manera, pusieron de manifiesto toda otra serie de elementos que no tenían que ver exclusivamente con la representación del propio cuerpo y el propio rostro: la incorporación de los vínculos familiares y afectivos, del espacio doméstico, de objetos relevantes del universo cotidiano de sus autores/as.

Será recién en esta década, con el uso de la herramienta fotográfica por parte de artistas provenientes de una formación en artes visuales cuando la estética fotográfica se vea marcadamente modificada, con la incorporación de recursos plásticos y conceptuales diferentes a los utilizados hasta el momento. Será aquí cuando el autorretrato fotográfico comienza a ser exhibido ampliamente dentro de los circuitos artísticos públicos y privados e incorpora el registro de situaciones íntimas y cotidianas de los autores. Veamos aquí algunas imágenes representativas de este cambio. 
Figura 4 - Cóctel

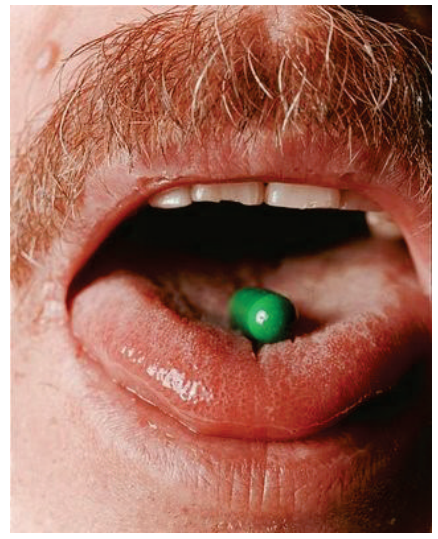

Fonte: Alejandro Kuropatwa

Esta fotografía (figura 4) pertenece a Alejandro Kuropatwa y la serie a la que pertenece se titula "Cóctel". En ella, el autor registra (y en ese acto, también, se registra a sí mismo) las píldoras que consumía para combatir el virus del HIV. Kuropatwa, que además trabajaba de fotógrafo comercial, en un estudio fotográfico en el que se retrataban importantes figuras de la cultura rock local, no tiene prejuicios en incorporar la estética publicitaria y utilizar en su obra los métodos de trabajo propios de ese lenguaje. Los campos se volvían más permeables. Para entonces, la fotografía estaba en pleno proceso de incorporación y relación con otros soportes de las artes visuales.

Si miramos el contenido del libro "Artistas argentinos de los noventa" editado en el año 2000 por el Fondo Nacional de las Artes, podemos advertir que la fotografía ingresa allí de la mano de artistas visuales que trabajaban con otros lenguajes, y son pocos los fotógrafos provenientes del campo fotográfico que aparecen allí. De los 57 autores contenidos en el libro, Alberto Goldenstein, Raúl Flores, Marcos López, Alejandro Kuropatwa, Andrea Ostera y Paula Zuker utilizan la fotografía como el lenguaje central en el 
desarrollo de su obra.

La elaboración y la puesta en circulación de estas imágenes de carácter autorreferencial permitieron a sus autores/as hablar de su propio mundo, de su experiencia cotidiana, mientras que a su vez conformaban discursos visuales de época e ilustraban un modo de estar en el mundo representado en una estética determinada. Los repertorios autorreferenciales dominantes en la (más) joven generación de fotógrafos/as de esta década se centraron en poner en evidencia el entorno en el que vivían (o incluso viven) e incorporar el registro de su vida cotidiana al cuerpo de su obra.

Con dispositivos narrativos más o menos elaborados, con técnicas más o menos sofisticadas que van desde la estética del "point and shoot" a puestas en escena pensadas y producidas para la imagen, lo autorreferencial comenzó a adquirir una serie de matices y variantes a explorar. Juan Travnik señala como distinción dos maneras que los/as fotógrafos/as poseen de vincularse con la fotografía: quienes van hacia el hallazgo y quienes construyen sus imágenes. En el campo de lo autorreferencial, esta distinción puede resultar de utilidad.

Entre los primeros, encontramos los trabajos de Guillermo Ueno e Ignacio Iasparra, pero esta lista podría ampliarse a muchos nombres más, ya que esta apelación a lo íntimo poético, a una estetización de lo cotidiano vuelto extraordinario por el modo en que es fotografiado, marca y funda un paradigma al que se suman numerosos autores más jóvenes. La "fotografía de luz edulcorada que todo lo roza" dirá Alberto Goldenstein que "se vuelve empalagante. Guillermo lo hace de una forma impecable, a él se lo permito por ser el primero", a lo que Travnik dirá "no es fácil hacer una foto a lo Ueno, iparece, pero no! Por eso es un estilo tan imitado, porque parece, pero no todas llegan..." Hay una manera de mirar el entorno de lo cotidiano inmediato que se ha establecido como una estética de referencia, reproducida por generaciones más jóvenes que imitan el estilo y dialogan con referentes internacionales que utilizan el mismo registro estético. Las imágenes son puestas en 
circulación en redes sociales y se alimentan de este canon global, de "estética joven", en los que los particularismos regionales se diluyen en el mundo de lo íntimo.

Volviendo a la clasificación propuesta por Travnik, en el segundo grupo, el de "quienes construyen imágenes", también encontramos exponentes que apelanaluniverso delo autorreferencial. Tal es el caso de Ananké Asseff. En su obra, la autora recurre a la utilización del propio cuerpo como materia prima para construir un discurso sobre la violencia, sobre la vulnerabilidad del cuerpo femenino. Compuesta de tomas cuidadosamente construidas, la serie denominada "Retazos del Paraíso (autorretratos)" (figura 5) reproduce distintas escenas que tienen a la fotógrafa como protagonista.

Figura 5 - Ananké Asseff

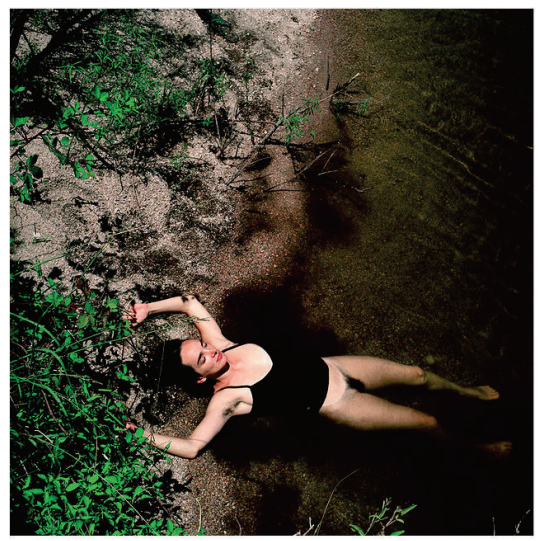

Fonte: Retazos del paraíso

Mientras que en el periodo anterior los autorretratos se proponían poner en relación la construcción de la propia imagen con comentarios y referencias a procesos políticos e históricos, contemporáneos o recientes, en este conjunto de autores la mirada se vuelve marcadamente intimista, centrada en sus relaciones afectivas 
inmediatas y los procesos de configuración de su subjetividad en términos de su propia experiencia vital personal: ser mujer, ser madre/padre, ser enfermo de VIH. Si bien estos elementos pueden emplazarse en discursos más amplios, los dispositivos narrativos a los que apelan no incluyen la experiencia de otros, como sí sucedía en los autores anteriores. Cuando Alejandro Kuropatwa construye las imágenes de sus cócteles, elabora un repertorio fotográfico autorreferencial que no pretende hablar del SIDA en términos abstractos o generales, sino que se propone hablar de su propia relación con la enfermedad, basada en su propia experiencia de vida y su propia rutina con la medicación asignada, y a partir de esta operación -de referir a su vinculación personal- habla del HIV como fenómeno social.

Otra diferencia importante con la generación anterior es que las fotografías de lo íntimo se vuelven más narrativas: ya no se limitan a registrar escenas estáticas como objetos y retratos sino que lo que la cámara irrumpe en algo que está sucediendo en el tiempo: un desayuno, una acción entre dos personajes, cualquier acción cotidiana. Con mayor o menor grado de construcción y de preproducción de la escena, el resultado documenta una secuencia particular: es un instante que recorta, la mirada del fotógrafo se detiene en ella. Al espectador la imagen le presenta un desafío: al incorporar una mayor cantidad de elementos y un manejo de la luz que apela a la operación mostrar/ocultar, la lectura se complica. Además, se ubican en el borde de una fotografía doméstica simple, sencilla. Guillermo Ueno dirá: "la fotografía es una técnica sencilla, a diferencia de la pintura por ejemplo" y el desafío es entonces ingresar a lo que allí se propone mostrar. Son fotografías que al acercarse al registro doméstico se alejan de la estética de la generación anterior. No sólo por la incorporación del color (en la obra de los referentes anteriores predomina el registro en blanco y negro) sino también por la utilización, en algunos casos, de cámaras compactas para el desarrollo de su obra.

Esto habilitó no sólo la producción de imágenes en esta 
clave por parte de autores más jóvenes sino también la revisión y edición de materiales de archivo por parte de los autores de la década anterior: todo aquello que había quedado por fuera de los circuitos exhibidores cuando las reglas del campo eran otras, ahora podía ser reconsiderado, puesto en relación con nuevas imágenes, construyendo otros dispositivos exhibidores más relajados. La igualación de imágenes técnicamente más logradas con imágenes defectuosas y la inclusión de imágenes de archivo elaboradas por otros junto a imágenes propias fueron las estrategias más frecuentes, estableciendo una convivencia de imágenes de diferentes orígenes.

Daniel Merle -que en el año 2008 realizó una muestra que ponía en relación fotografías de su álbum familiar (tomadas por su padre), con fotografías de su propia familia y su vida laboral (tomadas por él)- señala: "Nunca tuve, en realidad, nunca pensé como un artista, siempre me pensé más o menos como un fotógrafo en aprendizaje. La verdad, lo que yo hacía y hago aún hoy, experimento con la cámara para explorar una eficiencia técnica, sobre todo cuando era más chico... lo que hacía era probar con mis hijas para probar película, lentes, para probar y testear mis resultados... nunca hice mucha diferenciación entre mi trabajo y mi vida familiar, siempre está en los mismos rollos y siempre sigue estando bastante indiferenciado". El desplazamiento del campo fotográfico hacia la posibilidad de incorporar registros con esta estética permitió que imágenes elaboradas para "explorar una eficiencia técnica" fuesen incluidas en el cuerpo de la obra.

La muestra, reeditada este año en la fotogalería del Teatro San Martín y titulada "Mala memoria", recupera estos materiales y los exhibe nuevamente. Sin embargo, estas relaciones que el autor propone entre su vida personal y los registros de la vida pública mediante su actividad fotoperiodística no quedan en evidencia. Las imágenes se presentan en distintas paredes, sin terminar de establecer al espectador estos juegos entre unas y otras que el autor se propone. Por un lado, vemos las imágenes de su vida privada (sus hijas en el jardín de su casa o en interior de un departamento) y, en 
la pared siguiente, opuesta a esto, vemos imágenes de sus trabajos fotográficos: una serie de gente en situación de calle, unos paisajes urbanos del microcentro porteño y algunas imágenes de actualidad de su trabajo como reportero gráfico. ¿Qué relación -formal y de contenido- se puede establecer entre unas y otras? Pareciera que la articulación no es tan sencilla cuando el contenido de lo sociopolítico no se inscribe de forma evidente en la propia biografía, como lo vimos en el trabajo de Quieto. Aquí la subjetividad del autor no logra combinar estas dos esferas, la de lo íntimo familiar con lo público social de sus registros en la calle.

Y quizás el vínculo también se dificulta porque estamos ante formatos y estéticas diferentes. El riesgo con la fotografía es que, al estar inscripta en otros usos sociales, la incorporación de fotografías familiares a una exhibición en la que también se incluyen ensayos con otra estética, estas primeras queden relegadas a un lugar secundario, como datos de contexto, como registros elaborados con otra intensión y que el autor ahora desea incorporar a su obra $\mathrm{y}$ exhibirlas en estos términos. Merle elige conscientemente la incorporación de estas imágenes domésticas para ser exhibidas. Sin embargo, esta articulación que propone no se logra en términos de relato visual: en el montaje elegido en sala, las imágenes aparecen como pertenecientes a conjuntos diferentes, separadas entre sí, lo que dificulta al espectador establecer ese vínculo que el autor pretende. Lo que queda en evidencia es esta dificultad de establecer relaciones entre el mundo íntimo y el oficio.

\section{A modo de cierre}

A lo largo del artículo hemos advertido toda una serie de estrategias desplegadas por algunos referentes del campo fotográfico argentino en relación a la elaboración de repertorios fotográficos autorreferenciales dentro de su obra. Aquí también podemos advertir diferencias de género y grupo generacional, así 
como también diferentes modos en que se inscribe la historia político social del país en su propia obra, a partir de referencias biográficas que se proyectan más allá de su propia historia personal.

En las imágenes y relatos aquí analizados, queda en evidencia que son las mujeres fotógrafas las que más a menudo "colocan el cuerpo", mientras que los autorretratos de los autores varones eligen una estrategia mediada de presentación: sombras y reflejos, retratos grupales en los que se presentan con otros.

En las narrativas de lo íntimo en las que se despliega lo doméstico, el relato autorreferencial se construye a partir de una mostración poética del entorno inmediato. Estos fotógrafos no aparecen ante la cámara, su presencia está dada en la proximidad con lo representado en sus imágenes: son sus mujeres y sus hijos, su dormitorio y su cocina las que configuran y presentan la subjetividad del autor. Son así, repertorios fotográficos autorreferenciales que no ingresan estrictamente a la convención del autorretrato, del sujeto ante la cámara. Y en estas imágenes, abundan las mujeres, sus compañeras con las que conviven. Ellas son las protagonistas de estas imágenes.

Tanto Weisz como Asseff -salvando todo lo que las diferencia en otros aspectos, como los generacionales y estéticosutilizan su cuerpo como materialidad para construir otro discurso más amplio: no es una subjetividad individual sino un modo particular de relacionarse con ciertos aspectos del mundo. En el caso de los autorretratos de Weisz no pueden ser pensados por ella sin ser puestos en relación con otras mujeres en los que se acercan por su condición de género pero se distancian en su fisionomía: sus rasgos dan cuenta de marcas étnicas particulares, y se alejan así de la imagen de mujer blanca de la propia Weisz.

Cuerpos femeninos en la esfera privada o puestos en escena para dar lugar a imágenes construidas. Hombres públicos, reporteros gráficos construyendo los registros cotidianos de la agenda pública, intentando articularlos con sus historias personales, historia sociopolítica inscripta en biografías particulares. Cuerpos 
que indican, señalan, vehiculan y constituyen una idea de autor.

\section{Referencias}

GUMIER MAIER, Jorge; PACHECO, Marcelo. Artistas argentinos de los 90. Buenos Aires: Fondo Nacional de las Artes, 2000 .

LONGONI, Ana. Apenas, nada menos. En torno a 'Arqueología de la ausencia' de Lucila Quieto. Revista Ramona, Buenos Aires, $n$. 97, p. 56-61, 2009.

PÉREZ FERNÁNDEZ, Silvia. Apuntes sobre fotografía argentina a fin de siglo: hacia la construcción de un mercado. In: PÉREZ FERNÁNDEZ, Silvia; GAMARNIK, Cora. Artículos de investigación sobre fotografía. Montevideo: Editorial $\mathrm{CdF}$ Ediciones, 2011. 